\section{References}

1. Mack MJ, Leon MB, Thourani VH, Makkar R, Kodali SK, Russo M, et al. Transcatheter aortic-valve replacement with a balloon-expandable valve in low-risk patients. N Engl J Med. 2019;380:1695-705.

2. Okusanya OT, Hess NR, Luketich JD, Sarkaria IS. Technique of robotic assisted minimally invasive esophagectomy (RAMIE). J Vis Surg. 2017;3:116.
3. Coyan G, Wei LM, Althouse A, Roberts HG, Schauble D, Murashita T, et al. Robotic mitral valve operations by experienced surgeons are cost-neutral and durable at 1 year. J Thorac Cardiovasc Surg. 2018;156:1040-7.

4. Han JJ, Kelly JJ, Patrick WL, Iyengar A, Atkins M, Pietras C. Timeless lesson from the past and present leaders of cardiothoracic surgery part 2: character development. J Thorac Cardiovasc Surg. 2020;160:991-7.
See Article page 991.

\section{Commentary: Back to the future: Lessons from our residents}

\author{
Virginia R. Litle, MD
}

In Part I of the "Timeless Lessons From the Past and Present Leaders of Cardiothoracic Surgery," Han and colleagues ${ }^{1}$ reflected on 4 decades of presidential words of wisdom with regard to professional accomplishments including surgical excellence, mentorship, and scholarship. In Part II, the resident authors reflect on the character development aspects and categorize the talks into those of humanism, balance, leadership, and the future. ${ }^{2}$ Essentially all leaders discussed Leadership and the Future, whereas the Humanism and Balance content varied over time. As a mid- to senior-career academic surgeon and married mother of 3 , I will provide a female reflection of the valuable attributes of gratitude, well-being, and coaching to create a strong leader.

\section{HUMANISM: GRATITUDE AT THE CORE}

Echoing past leaders, we as healers are most grateful for the privilege of caring for others. That is the seed from which our professional success must grow. Dr Maddaus, in his recent raw and personal account of a life-changing event, outlined the science behind gratitude and relief of stress. ${ }^{3,4}$ Dr Rusch, in her American College of Surgeons Presidential Address, thanked those who provided guidance to her along her exemplary path to surgical leadership. ${ }^{5}$ The

\footnotetext{
From the Division of Thoracic Surgery, Department of Surgery, Boston University School of Medicine, Boston, Mass

Disclosures: Author has nothing to disclose with regard to commercial support.

Received for publication March 7, 2020; revisions received March 7, 2020; accepted for publication March 9, 2020; available ahead of print March 25, 2020.

Address for reprints: Virginia R. Litle, MD, Division of Thoracic Surgery, Department of Surgery, Boston University, 88 East Newton St, Collamore 7380, Boston,

MA 02118 (E-mail: Virginia.litle@bmc.org).

J Thorac Cardiovasc Surg 2020;160:999-1000

$0022-5223 / \$ 36.00$

Copyright (c) 2020 by The American Association for Thoracic Surgery

https://doi.org/10.1016/j.jtcvs.2020.03.048
}

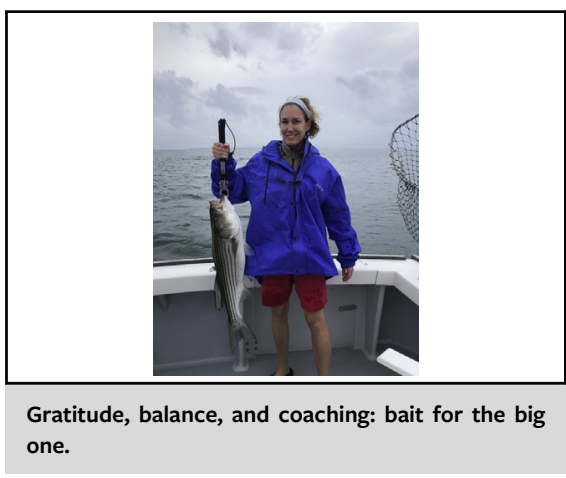

CENTRAL MESSAGE

The evolution of humanism, balance, and well-being in the words of past, present, and future leaders of cardiothoracic surgery.

times are a changin' and we are grateful for the support of our leaders in the \#HeforShe movement. Dr Patterson, in particular in his presidential address, appreciated that with a nadir in the number of residents pursuing cardiothoracic surgery, the other half of the talent pool (ie, women) must be attracted to our field. ${ }^{6}$ Speaking on behalf of Women in Thoracic Surgery, we are grateful for all the men who have attended our receptions and supported us on \#SoMe. The times have changed indeed.

\section{BALANCE: HEAL THYSELF}

The increasingly anachronistic term "work-life balance" is transitioning into terms of wellness and valuing self-care. "We can only take care of patients as humane surgeons if we protect our own humanity," write the resident authors. ${ }^{2}$ Regarding time management, Saunders, in the Harvard Business Review, suggested we create schedules that reflect our values: "1: Get clear what is important... 2: Define why they are important... 3: Fuse your priorities with your schedule." It may be possible in this era of evolving humanism for surgeons and "doctor heal thyself," to create your values-based schedule. 


\section{LEADERSHIP: COACH NOT CAPTAIN}

Finally, the importance of leaders appreciating the humanism of their charges. From Dr Cooper's Address: "We must not allow them to be treated either like cash cows or schoolboys in need of petty discipline." 8 Some of the happiest or least stressed surgeons I know are those who are salaried. Facts are a relative value unit-based compensation system contributes to lower job satisfaction. ${ }^{9}$ The "captain of the ship" mentality persists; however, in 2020, this approach has potential to be disruptive inside and out of the operating room. Coach should replace captain. ${ }^{10}$

\section{FUTURE}

Character development includes themes of humanism and well-being, and continue to be central to presidential addresses; however, there is a gaps need for the professional adaptation of the evolving definitions. The future shines bright.

\section{References}

1. Han JJ, Kelly JJ, Iyengar A, Patrick WL, Sultan I. Timeless lessons from the past and present leaders of cardiothoracic surgery part 1: professional accomplishment. J Thorac Cardiovasc Surg. 2019;158:1602-6.

2. Han JJ, Kelly JJ, Patrick WL, Iyengar A, Atkins M, Pietras C. Timeless lessons from the past and present leaders of cardiothoracic surgery part 2: character development. J Thorac Cardiovasc Surg. 2020;160:991-7.

3. Maddaus M. The resilience bank account: skills for optimal performance. Ann Thorac Surg. 2020;109:18-25.

4. Maddaus M. Beyond the Abstract: The Resilience Bank Account. STS Surgical Hot Topics Podcast Series; 2019.

5. Rusch VW. Presidential Address: The joys of learning, collaborating, and giving back. Bulletin, American College of Surgeons; 2019. Available at: https:// bulletin.facs.org/2019/12/presidential-address-the-joys-of-learning-collaboratingand-giving-back/. Accessed April 10, 2020.

6. Patterson GA. Non solus-a leadership challenge. J Thorac Cardiovasc Surg. 2010;140:495-502.

7. Saunders EG. Working parents: does your schedule reflect your values? Harvard Business Review. November 26, 2019. Available at: https://hbr.org/2019/11/ working-parents-does-your-schedule-reflect-your-values. Accessed April 10, 2020.

8. Cooper J. Presidential address 2003. J Thorac Cardiovasc Surg. 2006;132:747-52.

9. Lochner J, Trowbridge E, Kamnetz S, Pandhi N. Family physician clinical compensation in an academic environment: moving away from the relative value unit. Fam Med. 2016;48:459-66.

10. Williams BW, Williams MV. Understanding and remediating lapses in professionalism: lessons from the island of last resort. Ann Thorac Surg. 2020;109:317-24.

\title{
Commentary: Reflections on the past and how they impact reflections of ourselves
}

\author{
S. Adil Husain, MD
}

The American Association for Thoracic Surgery (AATS), founded in 1917, has long espoused as its core values leadership, education, and mentorship. In this issue of the Journal, Han and colleagues ${ }^{1}$ present their second manuscript in a 2-part series describing common thematic messages delivered by past presidents. More specifically, they

From the Division of Cardiothoracic Surgery, Departments of Surgery and Pediatrics, Heart Center, Primary Children's Hospital, Salt Lake City, Utah.

Disclosure: Author has nothing to disclose with regard to commercial support.

Received for publication March 16, 2020; revisions received March 16, 2020; accepted for publication March 17, 2020; available ahead of print April 9, 2020.

Address for reprints: S. Adil Husain, MD, Heart Center, Primary Children's Hospital, 100 N Mario Capecchi Dr, Suite 2200, Salt Lake City, UT 84113 (E-mail: adil. husain@hsc.utah.edu).

J Thorac Cardiovasc Surg 2020;160:1000-1

$0022-5223 / \$ 36.00$

Copyright (c) 2020 by The American Association for Thoracic Surgery

https://doi.org/10.1016/j.jtcvs.2020.03.108

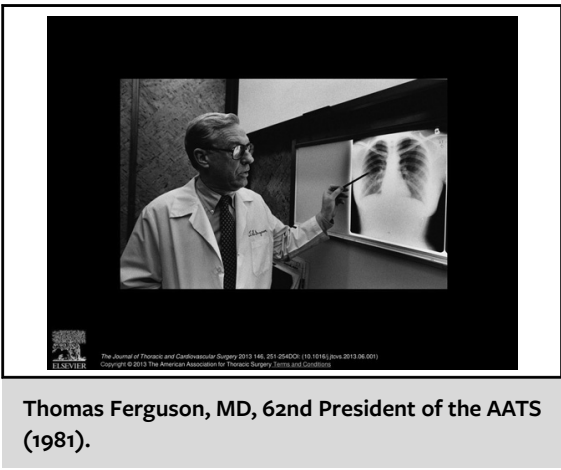

CENTRAL MESSAGE

Messages shared by past presidents of the AATS have similar themes regarding character development. Understanding these themes allows the reader to acquire presidential wisdom and concurrently engage in selfreflection. 